\title{
SHORT REVIEWS
}

\section{A Scientist Who Believes in God}

By Dr. H. N. V. Temperley. Pp. 176. (London: Hodder and Stoughton, Ltd., 1961.) 15s. net.

1 HERE is an increasing number of books by men of science concerning their faith and Dr. Temperley's is a welcome addition to the range. In the author's words: "The central problem is whether the whole body of evidence before us justifies the inference that the universe is directed by a Mind, or whether we must conclude that the existence of the human race is the accidental result of certain forces acting in a particular environment. . . . To sum up, the book is intended to be a survey of, and a guide to, the available evidence rather than an attempt to sell any particular brand of philosophy, theology or churchmanship, or any special scientific theory". Dr. 'Temperley has succeoded in this objoctive, and his desire to help young people to make up their minds about fundamental religious questions should receive wide recognition. Every thoughtful roader, whethor young or old, can benefit by this adequate and frank discussion of religious problems. No doubt the author's wide experience as teacher and research worker in physics and biophysies, both at Cambridge and in the United States, is reflected in his own confession of faith.

Special attention is directed to the case for the 'materialist evolutionary' theory of the universe, followed naturally by that for a 'theistic' interpretation. Specific lines of evidence such as that from within, from Christianity, and from other sects and faiths are pursued with clarity. Of special interest is a modern modification of Paley's woll-known teleological argument. The last chapter of the book is devoted to the author's own position and is all the more convincing as his journey back to belief was made from the realm of complete agnosticism.

\section{H. D. Anthony}

The World of Learning, 1961-62

Twelfth edition. Pp. xiv +1359 . (London: Europa Publications, Ltd., 1962.) 140s. net.

THE current edition of The World of Learning continues the policy of providing the widest possible guide to the world's cultural institutions, showing the addresses, and names of the leading officials, of the world's learned societies, research institutes, libraries and archives, museums and art galleries, universities, colleges and technical institutes. A list of the professors of most universities is also provided, and this year, in response to numerous requests, the telephone numbers of a large number of universities and certain other institutes have been included. It also includes details of Unesco, giving its origin, aims, functions and activities, followed by, in alphabetical treatment, each of the member countries.

The present edition shows an increase of eighty pages from the eleventh edition, necessitated by the rapid development of the newly emerged nations of Africa and Asia and the intensification of scientific and cultural activities in the rest of the world. The contribution from the U.S.S.R. shows a small increase, but still remains at the regrettably low figure of thirty-three pages, compared with the total of two hundred and twenty from the United States

It is to be regretted that The World of Learning still does not include a name index. With presentday 'punch-card' sorting techniques, such a compilation should not represent the impossible task that faced the organizers of Index Generalis when completing the twenty-first edition in 1955. The index to this massive work included something like 125,000 entries and extended it by some 400 pages. If necessary, the index to The World of Learning could be prepared as a supplement.

\section{Persons and Perception}

By Leslie Paul. Pp. 231. (London: Faber and Faber, Ltd., 1961.) 25s. net.

THIS volume is interesting more for some of its 'asides' than for its main theme. The author considers the reasonableness of metaphysical inquiry, the impasse over perception, the protest against bifurcation, the analysis of feeling, and the status of percepts. All this is not very much more than a book about books, mostly those of the great philosophers. But at the end of Chapter 1 we find-after a reference to the resthetic satisfaction of mathematical physics - a noteworthy paragraph on the present obsession with scientific specialization. Those, in fact, whose outlook is not scientific would be worse humanists if they were to abandon their own type of wisdom. Metaphysies, unfashionable no doubt, needs no apology or backward glances.

With this in mind, we turn to Chapter 4 and read a charming account of how any graceful bodily action is ruined if the performer becomes self-conscious. He simply does not know how it is done; mastery is completely natural. We all know this, but it is tempting to go a stage further (Dr. Leslie Paul does not quite venture thus far), and apply much the same criterion to accomplishments of the mind. Perhaps the greatest achievements in, for example, pure mathematics are entirely unselfconscious. They become something far less when pressed into service for the satisfaction of examiners, or even for an occasional lecture.

Along these lines, the axiology of thought will have to advance, if the author's metaphysical hopes are to reach fruition.

F. I. G. Rawlins

\section{The Coil of Life}

The Story of the Great Discoveries in the Iife Sciences. By Ruth Moore. Pp. $\mathrm{xv}+418+v i i+16$ plates. (London: Constable and Co., Ltd., 1961.) 40s. net.

D UTH MOORE is a science reporter to an American newspaper, and, in this book, combines flair for journalism and considerable scholarship to produce a dramatic account of the great discoveries in biology and allied sciences over the past 200 years. The story begins with Lavoisier, and, besides more familiar figures, describes the work of Bichat, 